\title{
The Effect Of Entrepreneurship Orientation On The Small Business Performance With Government Role As The Moderator Variable And Managerial Competence As The Mediating Variable On The Small Business of Apparel Industry In Cipulir Market, South Jakarta
}

\author{
Syahrul Effendi*, Djumilah Hadiwidjojo, Solimun, Noermijati \\ Doctorate Program in Management Faculty of Economics and Business, Brawijaya University, Malang
}

\begin{abstract}
This research is conducted based on the phenomenon of the apparel industry at Cipulir Market, South Jakarta in small business context. The production rate drastically decreased since the tight competition with the apparel product from China occurred when the free-trade policy was applied. Based on the literature review, small business sector decreased because of the lack of role from the entrepreneur, government, and managerial competence aspects. The purpose of this study was to quantify andexplain the effect ofentrepreneurial orientation on business performance and the moderating influence factors and the role of governmentas well as the factors mediating influence managerial competencies of entrepreneurial orientationon business performance. The method applied in this research was quantitative method. The location of the research was at Cipulir Market, South Jakarta. The research sample consisted of 255 people from the group of apparel industry in small business sector. Data analysis utilized PLS (Partial Least Square) technique. The result demonstrated that entrepreneurship orientation did not have any influence on the small business performance. The government role was not yet influential to strengthen the relationship between entrepreneurship orientation and business performance; yet, entrepreneurship orientation affected managerial competence. Managerial competence influenced small business performance; Managerial competence a requirement that entrepreneurial orientation capable of improving the small business performance.
\end{abstract}

Keywords: entrepreneurship orientation, managerial competence, government role, business performance

\section{Introduction}

Small business sector has considerable role to the overall economic development of a nation (1); yet, the improvement of the small business competitiveness often faces constraints since the tiny economic scale and limited resource availability. However, small business sector is able to implement flexibility for they have simple internal organization, quickly responds and adapts to every change (2). Small business needs to keep their flexibility in order to adapt to the environmental changes (3).

Some researchers mentioned that entrepreneurship is very crucial to the business performance improvement (4), (5); yet, the relationship between entrepreneurship orientation and performance is varied still (6), (7). Some research had proved positive significant relationship between entrepreneur orientation and the performance of SME (8); (9); (10); (11); (12). Some other research demonstrated the contradictory results that there was no relationship between entrepreneurship orientation and business performance (13); (14). The relationship between entrepreneurship orientation and performance still needs contingency conceptual framework to create a match among other constructs such as managerial competence and government support in order to achieve optimum performance (15). Many organizations have taken their effort to improve entrepreneurship orientation in their business (16); (17); nevertheless, it comes up a new argument stating that mere entrepreneurship orientation is not sufficient to enhance business performance. To support small business, it requires government role (18); (19). Further, Frank mentioned that government support on the small business sector was perceived by some experts as the key to achieve performance accomplishment of the business in the future time. Research on entrepreneurship orientation in long term period lately becomes a very interesting topic and relevant with the recent condition as every business practitioner must deliver satisfaction for each of the costumer (20).

Entrepreneurship orientation offers value-added by creating, developing, and maintaining the relationship with the customers (21). (22) stated that a manager who has courage to take a risk tends to prefer to introduce new product in order to respond the change of customer demand. This kind of manager is also proactive in the context of entrepreneurship related to the future perspective in taking initiative for anticipating and chasing new opportunity to take over the market (23); (24).

The objective of this research is to analyze and measure the influence of entrepreneurship orientation on SME performance, the role of entrepreneurship orientation on SME performance through government role as 
its moderator, the influence of entrepreneurship orientation on managerial competence, and the role of managerial competence on small business performance.

\section{A. Entrepreneurship Orientation.}

\section{Review Of Literature}

Schuler, (25), explained that entrepreneurship is an innovation creation to produce new product in an existing organization or in a new organization. Entrepreneurship is a process conducted by individuals in an organization both for their own interest and for organization interest by considering the resources that they possess (26). Jones \& Butler (27) described that entrepreneurship is a process that is run by an organization in a way that considers the available opportunity and enhance quality related to the production factors to achieve value-added. A successful entrepreneur in establishing his business does not only depend on his role but also on his orientation toward the organization itself; thus, entrepreneurship orientation is an important part since it can assist an individual to adapt to his working environment (28).

A rapid growth of the economic as occurring in Japan was rooted from the small business sector; it happened in The U.S. as well since small business sector created new job vacancies. Therefore, developing countries started to change their orientation related to the entrepreneurship aspect as they saw the experience of developed industrial countries' economic growth were supported by the SME sector. There is a difference on the starting point of the government attention on the SME development between developing countries and developed and industrial countries. Among developing countries, SME experiences tight competition and distressed from the huge scale business. SME itself has weakness in keeping its product quality; yet, SME sector is always connected to public interest and needs. Thus, government is willing to develop and protect SME. On the contrary, in the developed industrial country, SME gets huge attention as it has several positive potential factors to support national economics (29).

\section{B. Government Role}

Dahi (30) explained that government role was crucial to support small business performance; if there was no capital support from government, small business performance would not be achievable. Okhomina (31) also mentioned that positive environment was an important factor of the entrepreneurship successfulness. Environment factor such as supporting environment moderates the relationship between psychological traits and entrepreneurship orientation. Stam (32) explained that business performance would not run if there was no government assistance in providing capital support. Positive influence of the environment such as supporting environment has moderated the relationship among entrepreneurship orientation (33).

\section{Managerial Competence}

In the literature of strategic management, the importance of managerial competence in the successfulness of small business has been studied; however, it provides various conclusions. Managerial competence refers to personal skill which is oriented to tasks and related to the effective leadership (34); meanwhile, management practice is related to formal methodology utilization to ensure the operation of the organization (35).

It is mentioned that the role of managerial competence on the organizational performance depends on the growth and development of the organization (36). The indicators of the managerial competence used by Standard Chartered are interpersonal skill, initiative skill, and adaptive skill (37).

\section{Organizational Performance}

Drucker (37) explained that performance is "the level of achievement or obvious outcome that is obtained which sometimes is used to obtain positive result." Performance is also defined as the personnel's successfulness in achieving strategic objective from four perspectives: finance, customer, process, as well as learning and growth (39). The definition above implies that organizational performance is the management decisions' outcome to achieve particular objective in effective and efficient way. Keats (40) formulated brief conceptual framework of organizational performance by making a proposition that correlated entrepreneurship, environment effect, and performance. Related to SME performance, it had been described in some thoughts through scientific study, consultation, and business practice. The paradigmatic definition difference on the term of performance is distinguished from the development stages during examining and planning the business management. The research spectrum has been categorized into theoretical perspective. Business performance is the quality and quantity of the tasks achievement, both by individuals and by group or organization (41). There are five indicators used for measuring performance that are the preciseness in fulfilling demand, ability to maintain good relationship with customers, sufficient inventory, keeping quality of the product, and providing affordable price for customers. The research conceptual framework is presented as follow: 
Figure 1. Conceptual Framework of the Research

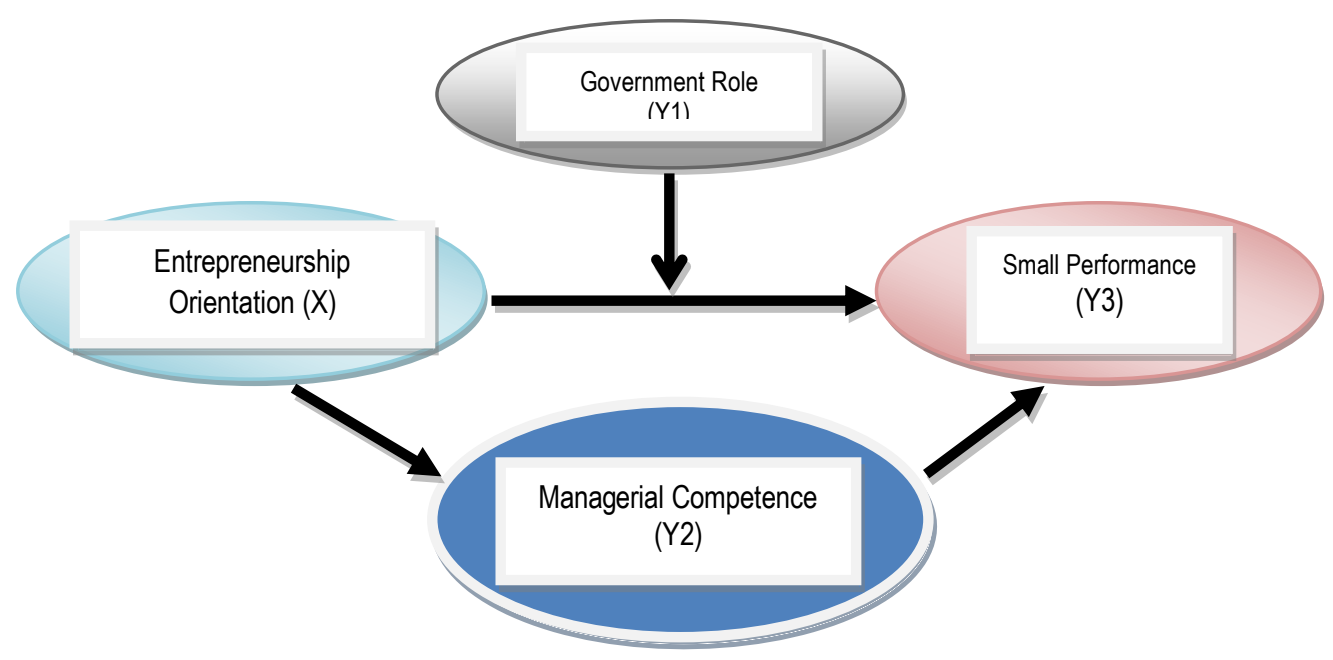

\section{Research Design}

III. Method

This research was design to utilize quantitative approach (positivism). Quantitative approach refers to empirical and rational principles of study because before conducting the research, it must be initialized by finding the occurring problems with some predetermined research criteria. Quantitative research deals with numbers; the data are numerical and analyzed by using statistical tools to answer research question or to examine the research hypothesis. It is specific for predicting that particular variable(s) affects other variable(s) (42).

\section{Research Location}

This research was conducted at Cipulir Market, South Jakarta. Cipulir Market was chosen by considering that this market had a potential to develop Small Business related to the apparel products that became the important and reliable product for the government.

\section{Population and Sample}

The population of this research is 700 small business practitioners dispersed over the Cipulir Market, South Jakarta. The sampling technique used proportional random sampling by drawing method. The sample amount was defined by using Slovin's formula; thus, it obtained 255 entrepreneurs/ business practitioners.

\section{Data Analysis Technique}

This research is aimed to examine and analyze the causal relationship between exogenous and endogenous variables both for intervening or dependent variables; it also checks the overall research instrument's validity and reliability. To do so, this research utilized Partial Least Square analysis technique that is assisted by Smart PLS application program.

\section{A. Profile of Cipulir Market}

\section{Result}

Kelurahan Cipulir, Kecamatan Kebayoran Lama at South Jakarta is well-known as one of the apparel product centers for pants that used Jeans as its raw material. One of the advantages of Cipulir Market is known as the wholesaler center of Textile and Textile Products in Jakarta. The practitioners in convection business generally have a kiosk/stand at Cipulir Market that ease them in selling their product that covers the area not only in Jakarta but also through all over regions in Indonesian archipelago. Small business at Cipulir Market has been established since 1989 for A Cluster; while for B Cluster, it was built in 1993. The numbers of kiosks at the recent day are 1,016 kiosks, respectively 700 old kiosks and 316 new kiosks.

\section{B. Description of the Respondent}


The description of the respondents consists of their sex, age, education background, the length the run the business, and the business scale (monthly turnover).

Tabel.1. Description of the Respondent

\begin{tabular}{|c|c|c|c|}
\hline No & Description & Amount & Percentage \\
\hline $\begin{array}{l}1 . \\
2 .\end{array}$ & $\begin{array}{l}\text { Sex } \\
\text { Male } \\
\text { Female }\end{array}$ & $\begin{array}{c}205 \\
50\end{array}$ & $\begin{array}{l}75 \\
25\end{array}$ \\
\hline & Total. & 255 & 100 \\
\hline $\begin{array}{l}1 . \\
2 . \\
3\end{array}$ & $\begin{array}{l}\text { Age } \\
0-30 \text { years old } \\
30 \text { years old }-40 \text { years old } \\
\text { More than } 40 \text { years old }\end{array}$ & $\begin{array}{c}40 \\
69 \\
146\end{array}$ & $\begin{array}{l}15 \\
18 . \\
57\end{array}$ \\
\hline & Total. & 255 & 100 \\
\hline $\begin{array}{l}1 . \\
2 . \\
3\end{array}$ & $\begin{array}{l}\text { Education Background } \\
\text { Junior High School } \\
\text { Senior High School } \\
\text { Bachelor }\end{array}$ & $\begin{array}{c}82 \\
150 \\
23\end{array}$ & $\begin{array}{l}20 \\
70 \\
10\end{array}$ \\
\hline & Total. & 255 & 100 \\
\hline $\begin{array}{l}1 . \\
2\end{array}$ & $\begin{array}{l}\text { Length of Business Establishment } \\
0-10 \text { years } \\
\text { More than } 10 \text { years }\end{array}$ & $\begin{array}{c}51 \\
204\end{array}$ & $\begin{array}{l}20 \\
80\end{array}$ \\
\hline & Total. & 255 & 100 \\
\hline $\begin{array}{l}1 . \\
2 . \\
3 \\
4 \\
5\end{array}$ & $\begin{array}{l}\text { Business Scale (Monthly Income) } \\
\text { Less than 2 Million } \\
\text { 2-4 Million } \\
\text { 5-7 Million } \\
\text { 8-10 Million } \\
\text { More than 10 Million }\end{array}$ & $\begin{array}{r}0 \\
5 \\
40 \\
169 \\
41\end{array}$ & $\begin{array}{r}0 \\
1.3 \\
25.3 \\
46.8 \\
26.6\end{array}$ \\
\hline & & 255 & 100. \\
\hline
\end{tabular}

Source : Primary Data, 2012

Based on the Table 1, the respondent's age that is more than 40 years old is 57 percent; while below 30 years old is only 10 percent. The length of the business establishment which is more than 10 years has the hugest number as it reaches 80 percent; whereas the small business establishment which is less than 10 years is 20 percent. The group of the old small businesses which have been established more than 10 years mostly are managed by entrepreneurs who are older than 40 years old; meanwhile, for less than 10 years of establishment, those are managed by entrepreneurs who are younger than 30 years old and who are between 30 to 40 years old for 15 percent and 18 percent respectively. Small business owner commonly has education background until middle school level (senior high school) and bachelor graduate with the score of 70 percent and 10 percent respectively. The monthly income from the sales of the production outcome in average reaches 8 to 10 million takes the highest average with 46.8 percent; meanwhile the second highest monthly average income of more than 10 million is 26.6 percent. This is because they have loyal customers who come from region other than Jakarta.

\section{Hypothesis Test Result}

The hypothesis test result is meant to answer the questions related the relationship among variables that consists of entrepreneurship orientation, government role, and managerial competence variables. The hypothesis test result is presented in the following figure and table 


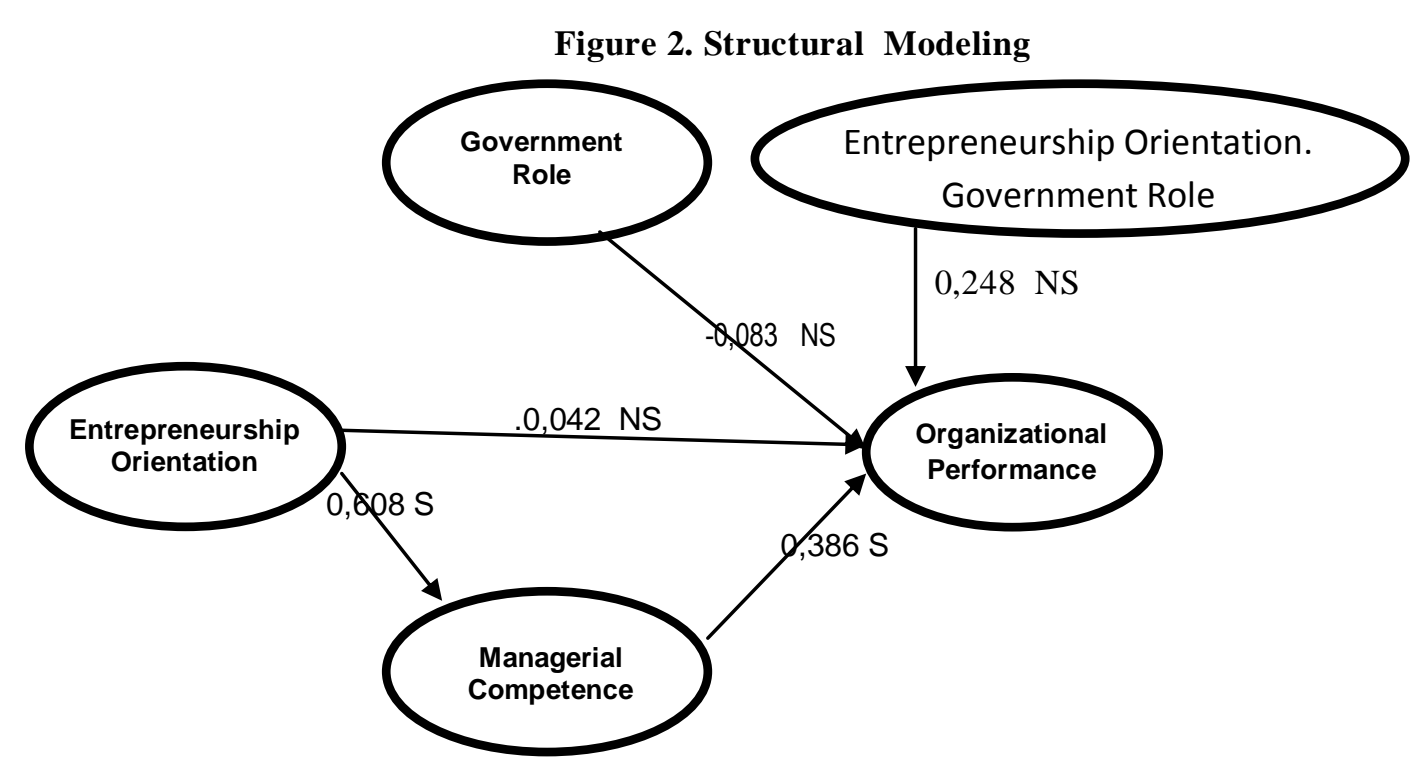

Table 2. Result of Inner Weight

\begin{tabular}{|l|c|c|c|l|}
\hline \multicolumn{1}{|c|}{ Relationship of Variables } & $\begin{array}{c}\text { original } \\
\text { sample } \\
\text { estimate }\end{array}$ & $\begin{array}{c}\text { Standard } \\
\text { deviation }\end{array}$ & T-Statistic & Description \\
\hline Entrepreneurship Orientation -> Performance & 0.042 & 0.258 & 0.163 & Not Significant \\
\hline Government Role-> Performance & -0.083 & 0.232 & 0.357 & Not Significant \\
\hline Managerial Competence-> Performance & 0.386 & 0.183 & 2.106 & Significant \\
\hline $\begin{array}{l}\text { Entrepreneurship Orientation-> Managerial } \\
\text { Competence }\end{array}$ & 0.608 & 0.261 & 2.332 & Significant \\
\hline X1*Y1 -> Performance & -0.248 & 0.361 & 0.689 & Not Significant \\
\hline
\end{tabular}

\section{Moderating Role Analysis}

The moderating variable of the model is a potential moderating variable. Potential moderating variable is a type of moderating variable that can be identified from the relationship's coefficient between government role and business performance. The coefficient statistically is not significant as the score 0.357 is lesser than the $\mathrm{t}$-table value; and, with alpha is 0.05 , it shows 1.645 . Further, it can be observed from the relationship's coefficient between the predictor variable and dependent variable. This variable does not interact with the predictor variable and does not have any significant relationship with the dependent variable.

\section{E. Mediating Role Analysis}

If the coefficient value of the relationship between entrepreneurship orientation and managerial competence is statistically significant, the value of 2.332 is higher than t-table value with alpha 0.05 that scores 1.645. The relationship's coefficient value between managerial competence and business performance is statistically significant since the value of 2.106 is higher than its t-table with alpha 0.05 that scores 1.645 . However, the relationship's coefficient between entrepreneurship orientation and business performance is not significant statistically; its score is 0.163 which is lesser than its t-table with alpha 0.05 that scores 1.645 . From this result, it is concluded that managerial competence can be stated as a complete mediation variable.

\section{Analysis And Discussion}

The research result demonstrated that entrepreneurship orientation did not significantly influence business performance of apparel industry at Cipulir Market, South Jakarta. Those small business practitioners at Cipulir Market commonly did not have high education background, since those who had higher education degree were few. It does affect the development of the entrepreneurship at Cipulir Market. The entrepreneurship insight is very important since those small businesses must face hard challenge when the free-trade agreement is applied. Other countries have made their entrepreneurs enormously enter Indonesian market; meanwhile, 
Indonesian small business at Cipulir Market is far left behind. Therefore, the entrepreneurship of the small business owners at Cipulir Market needs attention from several parties, mainly from the government. This research found similar finding with the prior research from Matsuno, Mentzer \& Ozsomer (2002), Sadler-Smith, E., Hampson, Y., Chaston, I., and Badger, B. (2003).

The research result showed that government role did not have significant role on the business performance. It indicated that so far, the government had taken effort to develop small business sector in Jakarta by issuing Kredit Usaha Rakyat (Loan for Small Business) and other programs; yet, in its implementation, it was not yet optimum since the bank appointed by the government required unreachable term and condition to apply for the loan for the small business. One of the term and condition that was required is collateral; meanwhile, small business commonly did not have any collateral in applying for loan to the bank. From this point, it is concluded that the government role is not yet able to moderate the relationship between entrepreneurship orientation and small business performance at Cipulir Market, South Jakarta. This finding is in resemblance with Dahi's research (2012).

The result also presented that entrepreneurship orientation had positive and significant effect on the managerial competence; further, managerial competence affected business performance positively and significantly. Even the small business entrepreneurs at Cipulir Market were not yet optimum in developing their business to reach export market, they had conducted hard effort at their best of the resources and ability that they possessed to adapt to the changing and developing era. Yet, they were only able to fulfill their daily needs and manage the cost to pay their employee's wage for 5 to 8 people. Thus, managerial competence is able to mediate the relationship between entrepreneurship orientation on the small business performance at Cipulir Market, South Jakarta.

\section{Conclusion}

Based on the problem formulation, research objective, hypothesis testing, and discussion, it can be concluded that entrepreneurship orientation is not yet able to enhance business performance. Creativity, courage to take a risk, flexibility, and anticipative dimensions commonly are not yet able to improve the performance of convection and apparel industry at Cipulir Market. The produced goods is not yet able to compete with the goods from both domestic and international markets. A reason why entrepreneurship orientation is not yet able to enhance business performance is related to education background. Commonly, they are Senior High School and Junior High School graduates; thus they are not able to develop their creativity in apparel production to attract customers. They do not have any courage to take risk since they simply think about the small amount of profit is not an important matter as long as they can fulfill their daily needs. They cannot think in flexible way and are not yet able to anticipate challenges in free-trade era so that they just leave it to the occurring condition. Government does not yet provide contribution to support entrepreneurship orientation. Even some policies for SME had been issued, its implementation did not meet the expectation of the apparel small business sector at Cipulir Market, South Jakarta. The bank appointed by the government does not have enthusiasm to distribute loan for the small business sector since this sector commonly is not able to provide requirements asked by the bank. The effort to develop small business sector taken by the bank which is appointed by the government only works on one entrepreneur who achieves the loan as credited by the bank; it does not work on the most of the existing small business units at Cipulir Market. Entrepreneurship orientation is able to improve managerial competence. Though only have limited capital, the small business units perceive that their businesses are sufficient. They also think that they are skillful in leading and able to synergize with the employees, as well as able to make proper decision. In fact, it can enhance business performance as they have good relationship with the customers, keep the product quality, maintain the punctuality of product demand, and provide sufficient inventory.

\section{References}

[1] Karjantoro, (2010). Usaha Kecil dan Problem Peniberdayaarinya. Jakarta,Usahawan, No.04.

[2] Sanchez, AM. and Marin, G.S. 2005. Strategic Orientation, Management Characteristics and Performance: A study of Spanish SMEs. Journal of Sniaii Business Management. Vol. 43. No. 43, pp. 287-308

[3] Glaiser, KW and P.J. Buckley. (1996). Strategic Motives for International Alliances Formation. Journal of Management Studies. Vol. 33, pp. 301-332

[4] James dan Timathy L Pett, (2006) High Performing Smes-Human Resource Practices And The Organizational Learning Process Journal of Management, 27: 755-775.

[5] Dutta, Jim Burns, R. Jain, Henning Schulzrinne, Ken Young, “A Multi-layered Mobility Management Scheme for Survivable Network, IEEE Milcom 2001, Vienna, VA

[6] Stam, Kashifa Suddle S. Jolanda A. Hessels Jena Economic Research Paper (2007)-019

[7] Lee, L. Y., \& Badri, M. S. (2007). The Effects of Expatriate Personality and Cultural Intelligence on the Expatriate Adjustment: The Moderating Role of Expatriate. Asia Pacific Management Conference. 13, pp. 922-931.

[8] ovin J. G., Green, K. M., \& Slevin, D. P. (2006). Strategic process effects on the entrepreneurial orientation-sales growth rate relationships. Entrepreneurship: Theory \&Practice, 30 (1), 57-81. 
[9] Wiklund, J. (1998), „Entrepreneurial orientation as predictor of performance and entrepreneurial in small firms: Longitudinal evidence., In P. D. Reynolds, W. D. Bygrave, N. M. Carter, P.Davidsson, W. B. Gartner, C. M. Mason e P. P.

[10] Lee, K. \& Pennings, J. M. (2001). Internal capabilities, external networks, and performance: a study on technology-based ventures. Strategic Management Journal, 22, 615-640

[11] Chow, I. (2006), „The relationship between entrepreneurial orientation and firm performance in China., S.A.M. Advanced Management Journal, vol. 71, no. 3, pp. 11-20.

[12] Atuahene-Gima, Kwaku and Ko, Anthony (2001). An Empirical Investigation of the Effect of Market Orientation and Entrepreneurship Orientation Alignment on Product Innovation. OrganizationScience 12(1):54-74.

[13] Matsuno, Mentzer \& Ozsomer,(2002), "The Effects of Entrepreneurial Proclivity and Market Orientation on Business Performance." Journal of Marketing 66 (3):18-32.

[14] Sadler-Smith, E., Hampson, Y., Chaston, I., and Badger, B. (2003). Managerial behavior,entrepreneurial style, and small firm performance, Journal of Small Business Management, vol.41(1), pp. 47-67.

[15] Lumpkin, G. T., \& Dess, G. G. (2001). Linking two dimensions of entrepreneurial orientation to business performance: The moderating role of environment and industry life cycle. Journal of Business Venturing, 16, 429-451.

[16] Covin, J. G., \& Slevin, D. P. 1989. Strategic management of small firms in hostile and benign environments. Strategic Management Journal, 10: 75-87

[17] Zahra, Shaker A. (1993), Environment, Corporate Entrepreneurship, and Financial Performance: A Taxonomic Approach, Journal of Business Venturing 8, 319-340.

[18] Hermann Frank/Alexander Kessler/Matthias Fink 2010; Entrepreneurial Orientation and Business Performance - A Replication Study SBR 62 April 2010 175-198 181

[19] Davis, J. L. (2007). Firm-Level Entrepreneurship and Performance: An Examination and Extension of Relationships and Measurements of the Entrepreneurial Orientation Construct. University of Texas at Arlington, Arlington

[20] Kuratko, D. F., \& Welsch, H. P. (2004). Strategic Entrepreneurial growth (2nd ed.). Ohio:Thomson, South-Western.

[21] Miller, D., \& Friesen, P. (1982). Innovation in conservative and entrepreneurial firms: two models of strategic momentum. Strategic Management Journal, 3, 1-25

[22] Kohli, Ajay and Jaworski, Bernard (1990). Market Orientation: The Construct, Research Propositions, and Managerial Implications. Journal of Marketing 54(2):1-18.

[23] Miller, D. 1983. "The Correlates of Entrepreneurship in Three Types of Firms."Management Science 29: 770-791.

[24] Venkatraman, N. (1989). Strategic orientation of business enterprises: The construct,dimensionality, and measurement. Management Science, 5(8), 942-962

[25] Schuler, (1986), Determinants of Human Resource Management Priorities and Implications for Usahaal Relations. Journal of Management Vol. 15. No. 1. 89-99

[26] Stevenson, H. H., \& Jarillo, J. C. 1990. A paradigm of entrepreneurship: Entrepreneurial management. Strategic Management Jou rnal [Special issue], 11: 17-27

[27] Jones, G R and Butler, J E (1992). "Managing Internal Corporate Entrepreneurship: An Agency Theory Perspective," Journal of Management, 18(4), 733-749

[28] Thornberry, (2006). Lead like an entrepreneur. Blacklick, OH: McGraw-Hill.

[29] Birch, D.L. (1979) The Job Generation Process. Final Report To Economic Development Administration. Cambridge, MA: MIT Program On Neighborhood And Regional Change

[30] Dahi Emine, Financial Challenges That Impede Increasing the Productivity of SMEs in Arab Region, Journal of Contemporary Management Submitted on 12/July/2012

[31] Okhomina. D.2008, Entrepreneurial orientation and psychological traits: the moderating influence of supportive environment. Journal of Behavioral Studies in Business

[32] Stam, E. (2010). Entrepreneurship, evolution and geography. In: Boschma, R. and Martin, R. L. (eds.), The Handbook of Evolutionary Economic Geography. Cheltenham, UK: Edward Elgar, 307-348

[33] Yeoh, P.-L., \& Jeong, I.I. (1995). Contingency relationships between entrepreneurship, export channel structure and environment. European Journal of Marketing, 29, 95-115.

[34] Martin, G. \& Staines, H. (1994): "Managerial Competence in small firms", Journal of Management Development, Vol. 13, No. 7, p. 23 - 34 Mattias Nordqvist, 2007

[35] Caglino, R. and Spina, G. (2002) A Comparison of Practice-performance Models between Small Manufacturers and Subcontractors, International Journal of Operations \& Production Management, 22(12), 1367-138

[36] Whitley, R. (1989) On the Nature of Managerial Tasks and Skills: Their Distinguishing Characteristics and Organization, Journal of Management Studies, 26, 209-224.

[37] Armstrong, J. S. (1994), "Replications and extensions in marketing: Rarely published but quite contrary," International Journal of Research in Marketing, $11,233-248$.

[38] Drucker (2002) Drucker, P. F. (1985). Innovation and Entrepreneurship: Practice and Principles, New York:Harper \& Row.European Journal of Social Sciences - Volume 20, Number 2 (2011)

[39] Mulyadi(2007). Sistem Terpadu Pengelolaan Kinerja Personel Berbasis Balanced Scorecard, Yogyakarta: UPP STIM YKPN

[40] Keats, B. W., \& DeMarie, S. M. (1998). Navigating in the new competitive landscape: building strategic flexibility and competitive advantage in the 21st century. Academy of Management Executive, 12 (4),22-42.

[41] Schermerhorn Jr., J. R., Hunt, J. G., \& Osborn, R. N. (2003). Performance of SMEs. International Journal of Productivity and Performance Management, 58 (3), 215-237.

[42] Creswell, J. W. (1994). Research design: Qualitative and quantitative approaches. Thousand Oaks, Ca: Sage Publications 